\title{
Assessment of Physico Chemical Parameters of Groundwater Quality Index of Palar Sub Basin using Remote Sensing and GIS
}

\author{
A.Anil, K. Chandra Sekhar Reddy, R.Bhavani
}

\begin{abstract}
The present project work is aimed toward assessing the water quality index (WQI) for the floor water of Palar Sub bowl. This technique has been picked by strategy for social affair groundwater tests and presenting the guide to an absolute physico engineered examination. The physico-engineered examination have been stood out from the extraordinary needed characteristics as empowered by technique for method for the field health relationship for ingesting and general prosperity that lets in you to possess unique a summary of this groundwater satisfactory assessment. For finding out Groundwater best in class Index following eleven parameters were thought about: $\mathrm{pH}$, Totalhardness, chlorides, Dissolvedsolids, calcium, Magnesium, sulfate, Nitrate, Flouride, Alkalinity, and sodium. The Water wonderful record for the ones sampl characteristics ranges from fifty 5.85 to 191.26. The most rate of Water first rate record has been explicitly from the better estimations of normal hardness, chlorides, Dissolved solids, Magnesium and alkalinity inside the ground water. using GIS forming strategies with ArcGis 10.1 Spatial movement maps of $\mathrm{pH}$, in vogue hardness, chlorides, Dissolved solids, calcium, Magnesium, sulfate, Nitrate, Flouride, Alkalinity, sodium and WQI were made. Water dumbfounding rundown changed into used to assess the suitability of groundwater from the look at an area for human confirmation. From the WQI appraisal over 90\% of the water tests fall in loathsome water bearings. The examinations most likely comprehended that the groundwater of the district dreams some acknowledgment of treatment before confirmation.
\end{abstract}

Index Terms:Physico-chemical analysis, Water Quality Index (WQI), Geographical Information system,Spatial analysis, Palar Sub basin.

Ground water happens virtually everywhere beneath the earth surface now not in single huge spread topographical arrangement anyway in a huge quantity of nearby aquifer frameworks and compartments that have comparative characters. records of the occasion, renewal and restoration of groundwater has superb criticalness in dry and semiarid districts because of disparity in rainstorm precipitation, poor surface waters and overabundance drafting of groundwater property.. bodily modifications within the beginning and constitution of the revived water, hydrological and human variables, may additionally purpose intermittent changes in groundwater excellent. figuring out the excellent is essential earlier than its usage for distinctive cause, as an instance, drinking, agrarian, recreational and present day use.till as of

Revised Manuscript Received on April 12, 2019.

A.Anil, Research scholar, Department of Civil Engineering, JNTUA, Ananthapuramu, A.P, India (anilachyutha@gmail.com)

K. Chandra Sekhar Reddy, Professor, Department of Civil Engineering, Siddhartha Institute of Engg\&Tech, Puttur A.P, India

(kamasani.kcr@gmail.com)

R.Bhavani, Associate Professor, Department of Civil Engineering, JNTUA, Ananthapuramu A.P, India (rbhavani77@yahoo.com)

\section{INTRODUCTION}

overdue, floor water assessment has been founded on studies center examination, yet the method of satellite tv for $\mathrm{pc}$ generation and Geographical records framework (GIS) may be a very helpful tool for creating solutions for water belongings problems surveying water nice[1,2,3].

Water Quality Index (WQI) is a maximum truthful technique for differentiating specific nature of groundwater and its appropriateness for exclusive cause. Water fine Index(WQI) is spoken to as an instrument of studying that gives the composite effect of person water nice parameters on the overall nature of water for human usage. WQI is a numerical condition used to trade massive wide variety of water high-quality records right into a solitary point[5].The gauges for drinking functions as prescribed by using WHO[4,5] has been taken into consideration for the estimation of WQI. Water satisfactory list is the most considerable apparatuses to impart facts on the character of any water body. It is straightforward to comprehension of water best administration and issues via incorporating gadget records and developing a score that portrays through and big water first-class popularity.

The principle quantity of this paintings is to speak approximately the appropriateness of groundwater for human utilization dependent on processed water quality list esteems and age of GIS maps.

\section{EXAMINE AREA}

Chittoor District is one of the industrious dry season motivated area of rayalaseema place of Andhra Pradesh. officially the region is isolated into 3 earnings divisions that are moreover subdivided in to 66 mandals. The precept seepage bowls are Bahuda, Pincha, swarnamuki, Palar, ponnai and araniyar. Palar Sub bowl lies between north latitude 13052' to 13038' and East Longitude 79054' to 790 $45^{\prime}$ with an all out waste $703 \mathrm{~km} 2$ (determine 1). It spread five mandals that is Chandragiri, somala, Puthalapattu.Irala and Pakala. The suggest temperature lies among to $30{ }^{\circ} \mathrm{C}$ to $42{ }^{\circ} \mathrm{C}$. The place is underlain by rocks of Archaean, proterozoic, jurassiic-caraceous and Tertiary-Quaternary ages. The maximum hooked up shake within the territory has an area with Migmatite complex, speakme to via migmatisedquartzo-feldspar gneiss and are uncovered in the northeastern piece of the locale. greater pro metamorphiccompriseamphibolites, hornblende-powder mica-schist,fuchsit quartzite, calcsillicate shake, marble and united ferruginous quartzite. The extra pro matamorphics

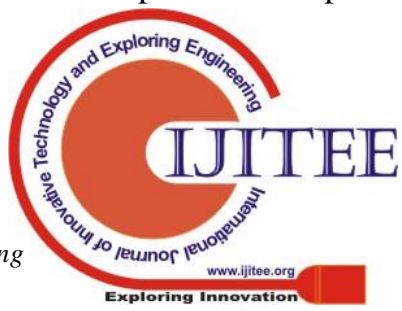




\section{Assessment Of Physico Chemical Parameters Of Groundwater Quality Index Of Palar Sub Basin Using Remote Sensing And Gis}

manifest as enclaves with peninsular Gneissic complex (\%). The investigation territory significantly covers stone gneiss shake kind and dolerite dykes and quartz veins are to be had. There are basically styles of soils present in the bowl they're red loamy soils and move guides are secured by using darkish dust soils.

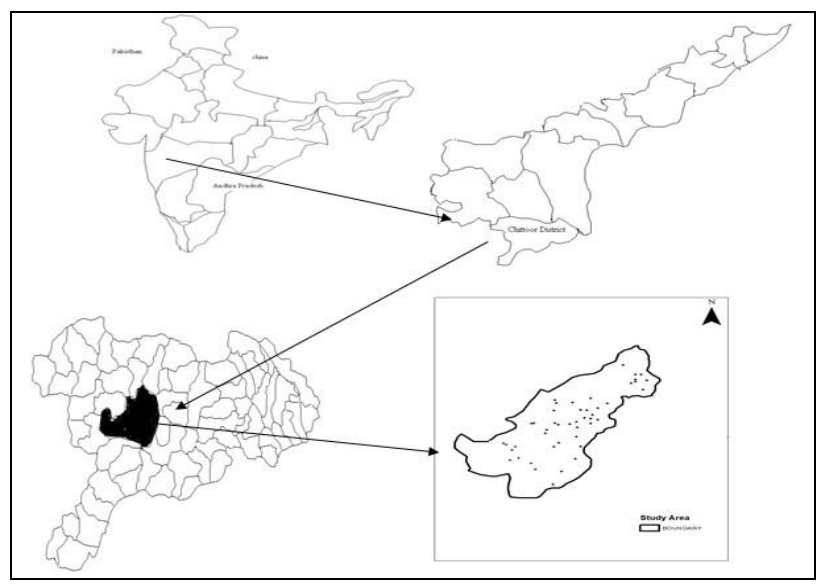

\section{CHEMICAL ANALYSIS}

Water tests had been amassed in July 2016 from 50 boreholes getting the significant aquifer of Palar Sub bowl. The water tests have been amassed in smooth polyethylene bottles. on the period of investigating, the containers were very well cases washed with the groundwater to be tried. inside the occasion of bore wells and hand siphons, the water tests were accumulated in the wake of guiding for 15 min. This become accomplished that lets in you to push off to groundwater set away inside the well. the majority of the groundwater test changed into inspected for 11parameters exhaustive of $\mathrm{pH}$, TDS, general hardness, Magnesium, Sulfate, Nitrate, Fluoride, Alkalinity, Sodium, Chlorides, Calcium. the usage of tremendous method enabled through APHA[6].pH is picked by method for the use of $\mathrm{pH}$ meter. typical solids are settled through using dispersal methodology. full scale hardness, calcium, magnesium, alkalinity and chlorides are settled with the guide of titration method. Nitrate is settled with the accommodating resource of BrusinSulphonic destructive strategy and sulfates are constrained by strategies for the usage of Turbedometeric approach. Flouride is picked by techniques for SPANDS strategy. Sodium is picked by methods for Flame photometer approach. most of the water quality parameters changed into imparted in $\mathrm{mg} / \mathrm{l}$, other than $\mathrm{pH}$.the cognizance of the compound appraisal have ended up being developed by techniques for figuring molecule parity botches. the mistake have been regularly round $12 \%$. every parameter end up being conversely with the most ideal surely understood keep of that parameter stipulated for exhausting water as suggested with the supportive resource of the part health business undertaking relationship for eating up and general prosperity features. GIS evaluation: The watch is finished with the assistance of topographic sheets, ERDAS and Arcview GIS 10.1. The toposheet of the Palar Sub bowl has a 1:50,000 scale and have advanced toward getting to be digitized to the UTM encourage gadget with the guide of applying the on display screen digitizing approach the utilization of ERDAS recognize as legitimate with programming framework program. GPS is used to plot condition of each inspecting borehole; and at closing, the results of each parameter separated had been familiar with the concerned boreholes. Spatial Analyst, a widely inclusive module of ArcGIS 9.3.,modified into used to find the spatiocommon lead of the groundwater first class parameters. The phenomenal topical layers on hardness, $\mathrm{pH}$ and ionic centers were dealt with using a spatial addition approach through Inverse Distance Weighted (IDW). This molding framework has been used inside the forefront day see to portray the locational movement of water poisons or segments.. This procedure uses a depicted or a specific course of action of model elements for estimating the yield grid adaptable cost. this can be pick the phone regards using a straightforwardly weighted aggregate of a fixed of model segments and it controls the centrality of showed up elements upon the embedded characteristics set up together totally surely as for their partition from the yield section, conveying thusly a surface lattice similarly as topical isolines [11]. Groundwater great class maps for $\mathrm{pH}, \mathrm{TH}, \mathrm{EC}, \mathrm{TDS}, \mathrm{Cl}$, $\mathrm{SO} 4, \mathrm{HCO}, \mathrm{NO}, \mathrm{Ca}, \mathrm{Mg}, \mathrm{Na}$ and F from topical layers, set up together completely generally as for the WHO necessities for ingesting water, were made for Palar Sub Basin.

\section{ESTIMATION OF WATER QUALITY INDEX}

Calculating water quality index(WQI), three steps were followed [7]. In the first start, every of the eleven parameters (pH, TDS, TH, Cl, SO4, HCO3, NO 3, Ca, Mg, $\mathrm{Na}$ and $\mathrm{F}$ ) has been assigned a weight supported their impact on primary health (Table 1).

maximum weight of 5 has been assigned to parameters like overall dissolved solids, fluorides and nitrate because of their major significance in water satisfactory evaluation. Bicarbonate is given the minimum weight of two as it plays a trifling role within the water exceptional evaluation [8]. other a few parameters like calcium, magnesium, sodium(Na) and sulphate were assigned a weight among 2 and five relying on their significance inside the general nice of water for drinking functions. inside the second step, the relative weight) of each parameter is computed the use of Eq. (1):

$$
W i=w i / \sum_{i=1}^{n} \text { wi }
$$

Where, is the weight of each parameter, is the number of parameters. Weight ( ), calculated relative weight

(Wil) values and the WHO standards for each parameter are given in Table 1 . In the third step, quality rating scale (qi) was calculated for each parameter using Eq. (2):

$$
q i=\frac{C i}{s i} \times 100
$$

$\mathrm{q1}^{11}$ is the quality rating, ${ }^{\mathrm{ci}}$ is the concentration of each chemical parameter in each water sample in $\mathrm{mg} / \mathrm{l}$ and $\mathrm{si}$ is the WHO standard for each chemical parameter in $\mathrm{mg} / \mathrm{l}$

In WQI, the SI is first determined for each chemical parameter using Eq. (3)-which is then used to determine the WQI as per the Eq. (4): 


$$
S I=W i x q i
$$

$$
W Q I=\sum_{i=1}^{n} S I i
$$

where, ${ }^{\text {SIi }}$ is the sub-index of ${ }^{\mathfrak{I}}$ th parameter. ${ }^{W Q 1}$ Values are usually classified into five categories (Table 2): Excellent, good, poor, very poor and unfit for drinking $[9,10]$.

Table 1: Status of Water Quality based on WQI

\begin{tabular}{|l|l|}
\hline WQI Range & Status \\
\hline$<50$ & Excellent \\
\hline $50-100$ & Good \\
\hline $100-200$ & Poor \\
\hline $200-300$ & Very Poor \\
\hline$>300$ & Unfit For Drinking \\
\hline
\end{tabular}

Table 2: Relative weight of chemical parameters

\begin{tabular}{|l|c|c|c|}
\hline $\begin{array}{l}\text { Chemical } \\
\text { Parameters }\end{array}$ & $\begin{array}{l}\text { WHO } \\
\text { Standards }\end{array}$ & $\begin{array}{l}\text { Weight } \\
\text { Win }\end{array}$ & $\begin{array}{l}\text { Relative Weight } \\
\text { Wi }=\text { wi } / \sum^{\text {wi }}\end{array}$ \\
\hline $\mathrm{pH}$ & $7.0-8.5(8.5)$ & 4 & 0.108 \\
\hline $\mathrm{TH}(\mathrm{mg} / \mathrm{l})$ & $100(\mathrm{mg} / \mathrm{l})$ & 2 & 0.054 \\
\hline $\mathrm{Cl}(\mathrm{mg} / \mathrm{l})$ & $200(\mathrm{mg} / \mathrm{l})$ & 3 & 0.081 \\
\hline $\begin{array}{l}\mathrm{TDS} \\
(\mathrm{mg} / \mathrm{l})\end{array}$ & $500(\mathrm{mg} / \mathrm{l})$ & 5 & 0.135 \\
\hline $\mathrm{Ca}(\mathrm{mg} / \mathrm{l})$ & $100(\mathrm{mg} / \mathrm{l})$ & 2 & 0.054 \\
\hline $\mathrm{Mg}(\mathrm{mg} / \mathrm{l})$ & $30(\mathrm{mg} / \mathrm{l})$ & 2 & 0.054 \\
\hline So3 $(\mathrm{mg} / \mathrm{l})$ & $250(\mathrm{mg} / \mathrm{l})$ & 4 & 0.108 \\
\hline $\mathrm{Nitrate}(\mathrm{mg} / \mathrm{l})$ & $50(\mathrm{mg} / \mathrm{l})$ & 5 & 0.135 \\
\hline $\mathrm{F}(\mathrm{mg} / \mathrm{l})$ & $1(\mathrm{mg} / \mathrm{l})$ & 5 & 0.135 \\
\hline $\mathrm{HCo}(\mathrm{mg} / \mathrm{l})$ & $100(\mathrm{mg} / \mathrm{l})$ & 2 & 0.054 \\
\hline $\mathrm{Na}(\mathrm{mg} / \mathrm{l})$ & $200(\mathrm{mg} / \mathrm{l})$ & 3 & 0.081 \\
\hline & & $\sum w i=37$ & 0.999 \\
\hline
\end{tabular}

WQI Contour Maps through GIS: GIS could be a powerful tool for developing solutions for water resources problems for assessing water quality, determining water availability, preventing flooding, understanding the natural environment, and managing water resources on area or regional scale [11]. Visiting each location in an exceedingly study space to live the peak, magnitude, or concentration of a phenomenon is usually difficult or expensive. Instead, measure the phenomenon at strategically dispersed sample locations, and foreseen values is allocated to any or all one of a kind places. The interpolation gear square measure typically divided into settled and geostatistical approaches. IDW, backbone, and fashion are deterministic, even as Ranging is a geostatistical method. The Inverse Distance Weighted (IDW) introduced up as settled interpolation approaches due to they assign values to locations supported the encompassing measured values and on such mathematical formulation that verify the smoothness of the ensuring surface. Determines the mobile values using a linearly weighted 'mixture of a group of pattern factors and controls the importance of wonderful factors upon the interpolated values. Groundwater quality classification maps for $\mathrm{pH}$ scale, TH, TDS, $\mathrm{Cl}, \mathrm{SO} 4, \mathrm{HCO}$, $\mathrm{NO} 3, \mathrm{Ca}, \mathrm{Mg}, \mathrm{Na}$ and $\mathrm{F}$ from thematic layers, supported the World Health Organization Standards for drinking water, have been created for Palar Sub Basin.

\section{RESULTS AND DISCUSSION}

$p H$

$\mathrm{pH}$ is one of the foremost important operational water quality parameters with the optimum $\mathrm{pH}$ required often being in therange of 7.0-8.5. The maximum permissible limit for $\mathrm{pH}$ in drinking water as given by the World Health organization is 8.5 . The values of $\mathrm{pH}$ in the groundwater samples collected varied from 6.28 to 7.48 with an average value of 6.88. Spatial distribution of $\mathrm{pH}$ concentrations are shown in Figure.2.

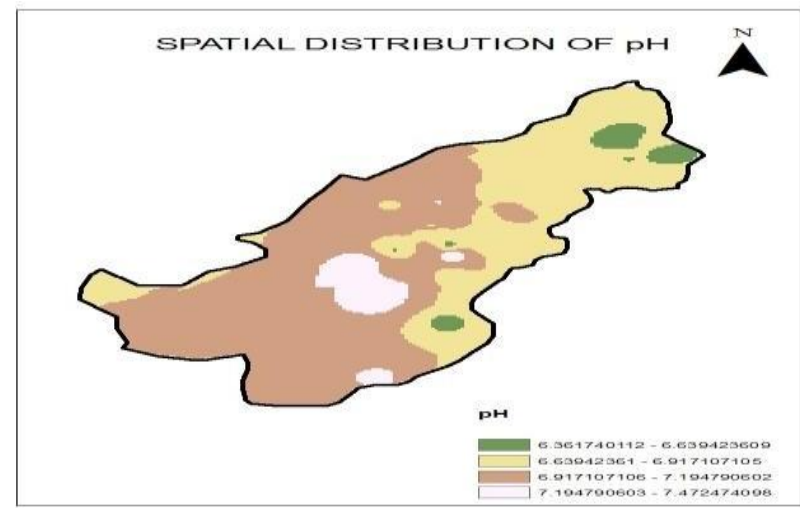

Figure 2: Spatial distribution of $\mathbf{p H}$

\section{Total Dissolved Solids (TDS)}

Concentration of dissolved solids in groundwater decides its pertinence for drinking, irrigation or industrial purposes. The concentration of dissolved matter in water is given by the weight of the material on evaporation of water to dryness up to a temperature of $1800 \mathrm{C}$. The values are expressed in $\mathrm{mg} / \mathrm{l}$. The major constituents of TDS include Bicarbonates (HCO) Sulphates (SO 2+) and Chlorides (Cl-) of Calcium, Magnesium, Sodium and Silica. Groundwater containing over one thousand $\mathrm{mg} / \mathrm{l}$ of total dissolved solids is usually referred as briny water. In the study area, the TDS amount ranges from $350 \mathrm{mg} / \mathrm{l}$ to $1300 \mathrm{mg} / \mathrm{l}$ with an average of $781 \mathrm{mg} / \mathrm{l}$. The spatial distribution of TDS concentrations are shown in Figure.3.

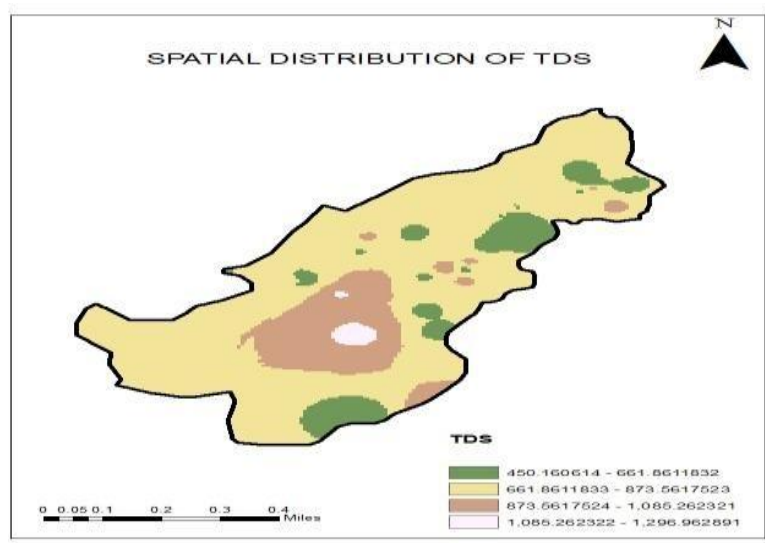

Figure3: Spatial distribution of TDS

Published By 
Table 3: Water Quality parameters Valuesfor collected Groundwater samples at various locations

\begin{tabular}{|c|c|c|c|c|c|c|c|c|c|c|c|c|}
\hline & & & $\mathrm{TH}$ & $\mathrm{SO}_{4}{ }^{2-}$ & Fluoride & $\mathrm{CL}^{-}$ & TDS & $\mathrm{Ca}^{2+}$ & $\mathrm{Mg}^{2+}$ & $\mathrm{Na}^{2+}$ & $\mathrm{NO}_{3}{ }^{-}$ & Alkalinity \\
\hline Sample & $\mathbf{T}\left({ }^{\circ} \mathbf{C}\right)$ & $\mathrm{pH}$ & & & 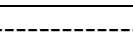 & $\cdots$ & - & $-m g / 1$ & ------. & $\ldots$ & $\ldots$ & ---- \\
\hline 1 & 33.5 & 6.54 & 380 & 17.7 & 0.2 & 166 & 550 & 231 & 125 & 100 & 1.2 & 221 \\
\hline 2 & 30 & 7.32 & 160 & 15.2 & 0.1 & 157 & 890 & 65 & 72 & 258.5 & 0.1 & 65 \\
\hline 3 & 33 & 6.76 & 220 & 9.65 & 0.3 & 59 & 950 & 105 & 92 & 90 & 0.1 & 95 \\
\hline 4 & 33 & 6.60 & 450 & 20.75 & 0.2 & 279 & 970 & 265 & 232 & 91.8 & \begin{tabular}{|l|}
0.25 \\
\end{tabular} & 256 \\
\hline 5 & 31 & 6.84 & 270 & 14.45 & 0.3 & 124 & 450 & $\begin{array}{l}158 \\
\end{array}$ & 89 & 104.9 & 1.1 & 148 \\
\hline 6 & 30 & 6.65 & 240 & 12.5 & 0.2 & 54 & 650 & 91 & 125 & 85.6 & 0 & 98 \\
\hline 7 & 32 & 6.75 & 280 & 16.75 & 0.3 & 89 & 550 & 138 & 119 & 68 & 0 & 128 \\
\hline 8 & 30 & 6.36 & 280 & 10.3 & 0.2 & 32 & 550 & 165 & 92 & 50.6 & 0.1 & 155 \\
\hline 9 & 31 & 6.76 & 390 & 20.3 & 0.2 & 121 & 850 & 145 & 222 & 108.2 & 0.1 & 138 \\
\hline 10 & 31 & 6.71 & 250 & 13.65 & 0.3 & 69 & 450 & 78 & 149 & 97.2 & \begin{tabular}{|l|}
0.45 \\
\end{tabular} & 68 \\
\hline 11 & 31 & 6.52 & 340 & 18.55 & 0.3 & 179 & 850 & 265 & 52 & 96.7 & 0.4 & 255 \\
\hline 12 & 34 & 7.02 & 440 & 13.8 & 0.2 & 149 & 850 & 198 & 219 & 110.1 & 0 & 188 \\
\hline 13 & 30 & 7.48 & 420 & 24 & 0.2 & 114 & 850 & 231 & 165 & 106.9 & 0 & 227 \\
\hline 14 & 30 & 6.61 & 460 & 25.5 & 0.2 & 214 & 950 & 231 & 205 & 111.3 & \begin{tabular}{|l|}
0.75 \\
\end{tabular} & 221 \\
\hline 15 & 32 & 6.89 & 460 & 25.05 & 0.2 & 224 & 1050 & 298 & 139 & 106.1 & 0.8 & 258 \\
\hline 16 & 29 & 6.87 & 470 & 25.2 & 0.1 & 214 & 950 & 231 & 215 & 137.8 & 1 & 221 \\
\hline 17 & 31 & 6.85 & 460 & 19.65 & 0.2 & 164 & 950 & 248 & 189 & 53.4 & 0.25 & 238 \\
\hline 18 & 33 & 6.55 & 260 & 12.25 & 0.2 & 49 & 550 & 165 & 72 & 39 & 0.6 & 155 \\
\hline 19 & 31 & 6.77 & 260 & 11.95 & 0.2 & 54 & 550 & 148 & 89 & 45 & 0.6 & 138 \\
\hline 20 & 31 & 6.28 & 280 & 10.95 & 0.2 & 124 & 550 & 165 & 92 & 42 & 0.45 & 155 \\
\hline 21 & 32 & 6.43 & 210 & 12.05 & 0.3 & 29 & 350 & 98 & 89 & 41.4 & 1.2 & 88 \\
\hline 22 & 32 & 6.84 & 450 & 22.95 & 0.2 & $\begin{array}{l}109 \\
\end{array}$ & 950 & 198 & 229 & 105.7 & 0 & 188 \\
\hline 23 & 31 & 6.44 & 460 & 29.35 & 0.2 & 114 & 950 & 215 & 222 & 83.5 & 0 & 205 \\
\hline 24 & 32 & 6.95 & 440 & 23.85 & 0.2 & 119 & 1050 & 331 & 85 & 108.7 & 0.45 & 335 \\
\hline 25 & 31 & 6.60 & 320 & 19.45 & 0.3 & 119 & 650 & 165 & 132 & 71.3 & 0 & 155 \\
\hline 26 & 31 & 7.25 & 500 & 16.9 & 0.1 & 214 & 950 & 198 & 279 & 86.6 & 1.4 & 188 \\
\hline 27 & 32 & 7.16 & 260 & 24.3 & 0.4 & 314 & 1050 & 315 & 72 & 191.1 & 1.6 & 305 \\
\hline 28 & 30 & 6.39 & 450 & 33.2 & 0.1 & 184 & 950 & 181 & 245 & 105.3 & 0.9 & 171 \\
\hline 29 & 30 & 7.23 & 260 & 12.7 & 0.2 & 41 & 450 & 148 & 89 & 39.4 & 1.1 & 138 \\
\hline 30 & 30 & 7.02 & 380 & 15.85 & 0.2 & 132 & 850 & $\begin{array}{ll}198 \\
\end{array}$ & 159 & 97 & 0.25 & 188 \\
\hline 31 & 32 & 6.75 & 280 & 7.2 & 0.2 & 49 & 750 & 131 & 125 & 47.6 & 0.6 & 121 \\
\hline 32 & 30 & 6.78 & 440 & 19.7 & 0.2 & 114 & 950 & 181 & 235 & 83.6 & 0 & 171 \\
\hline 33 & 32 & 6.83 & 460 & 20.15 & 0.1 & 116 & 950 & $\begin{array}{ll}198 \\
\end{array}$ & 239 & 110.9 & 1 & 188 \\
\hline 34 & 31 & 7.18 & 250 & 10.85 & 0.1 & 47 & 550 & 148 & 79 & 42.6 & 0.5 & 138 \\
\hline 35 & 31 & 6.85 & 380 & 13.7 & 0.2 & 121 & 750 & 181 & 175 & 69.6 & 1.2 & 171 \\
\hline 36 & 31 & 6.68 & 440 & 25.35 & 0.2 & 134 & 850 & 198 & 219 & 94 & 1.1 & 188 \\
\hline 37 & 32 & 6.85 & 280 & 10.45 & 0.1 & 119 & 550 & 131 & 125 & 125.9 & 0.7 & 121 \\
\hline 38 & 30 & 7.20 & 280 & 6.75 & 0.1 & 39 & 550 & 131 & 125 & $\begin{array}{l}50.9 \\
\end{array}$ & 1.6 & 121 \\
\hline 39 & 30 & 6.79 & 260 & 6.3 & 0.1 & 39 & 550 & 265 & 12 & 58.1 & 1.7 & 255 \\
\hline 40 & 30 & 6.78 & 280 & 2.7 & 0.1 & 44 & 550 & 98 & $\begin{array}{l}159 \\
\end{array}$ & 48.2 & 0 & 88 \\
\hline 41 & 30 & 7.10 & 420 & 11.1 & 0.1 & 131 & 750 & 165 & 232 & 69.2 & 0 & 155 \\
\hline 42 & 30 & 7.20 & 340 & 36.75 & 0.1 & 199 & 850 & 231 & 85 & 113.3 & 0.7 & 221 \\
\hline 43 & 32 & 7.26 & 490 & 36 & 0.2 & 204 & 1020 & 265 & 252 & 98.4 & 0 & 255 \\
\hline 44 & 31 & 7.18 & 280 & 7 & 0.2 & 41 & 450 & 98 & 159 & 49.9 & 1.4 & 88 \\
\hline 45 & 31 & 7.08 & 380 & 17.35 & 0.2 & 87 & 650 & 131 & 225 & 73.8 & 0.45 & 121 \\
\hline 46 & 31 & 7.11 & 360 & 17.8 & 0.2 & 89 & 750 & 181 & 155 & 82.7 & 0.1 & 171 \\
\hline 47 & 31 & 7.26 & 470 & 16.35 & 0.3 & 161 & 950 & 231 & 215 & 58.1 & 1.6 & 221 \\
\hline 48 & 30 & 7.44 & 610 & 26.5 & 0.3 & 399 & 1300 & 165 & 422 & 166.9 & 1.4 & 155 \\
\hline 49 & 30 & 7.42 & 560 & 26.45 & 0.1 & 399 & 1150 & 265 & 272 & 176.5 & 1.6 & 255 \\
\hline 50 & 30 & 6.84 & 500 & 16.7 & 0.1 & 224 & 1050 & 231 & 245 & 120.5 & 1.6 & 221 \\
\hline
\end{tabular}

\section{Total Hardness (TH)}

Hardness in water is caused primarily by the presence of carbonates and bicarbonates of $\mathrm{Ca}, \mathrm{Mg}$, Sulphates, Chlorides and Nitrates. Total hardness is a measure of $\mathrm{Ca} 2+$ and $\mathrm{Mg} 2+$ content in water and is expressed as equivalent of 
$\mathrm{CaCo} 3$. Water with hardness not greater than $75 \mathrm{mg} / \mathrm{l}$ is considered as soft. Hardness of $75-150 \mathrm{mg} / \mathrm{l}$ is not offensive for most purposes. Hardness minimum value of $160 \mathrm{mg} / \mathrm{l}$ and maximum value of $610 \mathrm{mg} / \mathrm{l}$. The spatial distributions of Total Hardness concentrations represented in Figure.4.

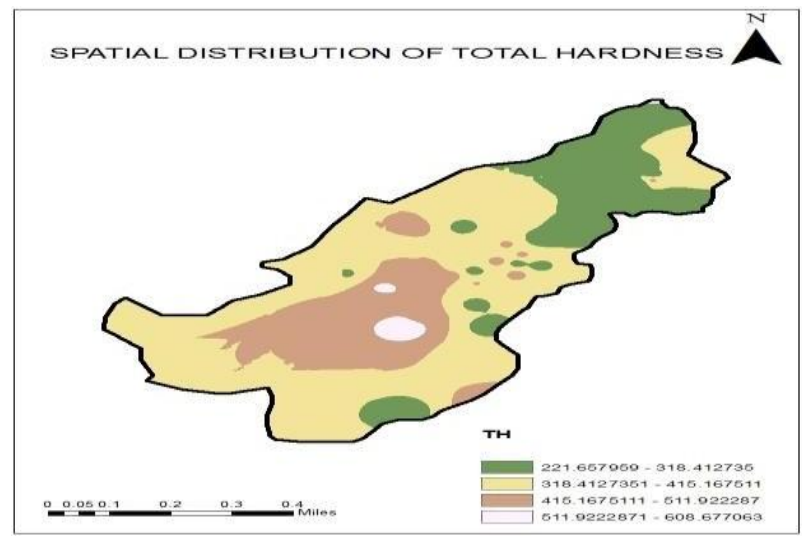

Figure 4: Spatial distribution of TH

Sulphate (So4)

Sulphates available in natural waters at concentration up to $50 \mathrm{mg} / \mathrm{l}$. concentration of $1000 \mathrm{mg} / \mathrm{l}$ can be found in water having contact with certain geological formations such as pyrite, lignite and coal. Sulphate concentration ranges from $3 \mathrm{mg} / \mathrm{l}$ to $40 \mathrm{mg} / \mathrm{l}$. The spatial distribution of chloride concentrations are shown in Figure.5

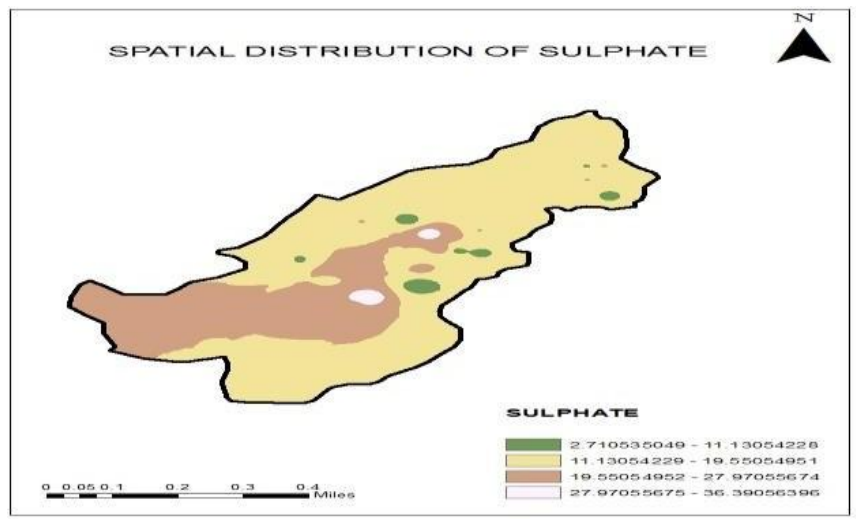

Figure 5: Spatial distribution of Sulphate

\section{Chloride $(\mathrm{Cl})$}

Chloride is held in all natural waters at greatly numerous cognizance depending at the geochemical conditions. essential property of chloride in groundwater are the materials of igneous and metamorphic rocks like gneiss and granite and so on. due to sewerage disposal and leaching of saline residues inside the soil, ordinary chloride concentrations also can rise up. Chlorides can handiest be eliminated with the aid of reverse osmosis system and electrolysis.chloride concentration of collected samples ranges from $29 \mathrm{mg} / \mathrm{l}$ to $400 \mathrm{mg} / \mathrm{l}$. The spatial distribution of chloride concentrations represented in Figure.6

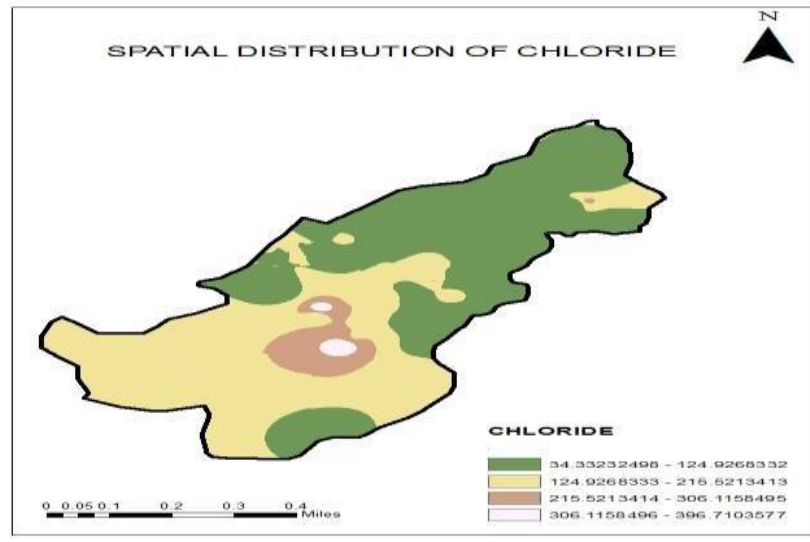

Figure 6: Spatial distribution of Chlorides

\section{Bicarbonates (HCO3)}

Alkalinity is provoked because of carbonates, bicarbonates and hydroxides of calcium, magnesium, potassium and sodium. $\mathrm{CaCo} 3$ is the most in vogue constituent that causes alkalinity. Bicarbonate is communicated in $\mathrm{mg} / \mathrm{l}$ as caco3 and for drinking water limited to a hundred $\mathrm{mg} / \mathrm{l}$ as caco3. in vogue Bicarbonate inside the Palar Sub bowl groundwater levels among sixty five $\mathrm{mg} / \mathrm{l}$ to $335 \mathrm{mg} / \mathrm{l}$. Water having bicarbonate not more prominent than $100 \mathrm{mg} / \mathrm{l}$ as caco3 is suitable for home admission. greater alkalinity in home grown waters will support of makers (green growth and phytoplankton companies) The spatial circulation of bicarbonate focuses are shown in discern. 7 .

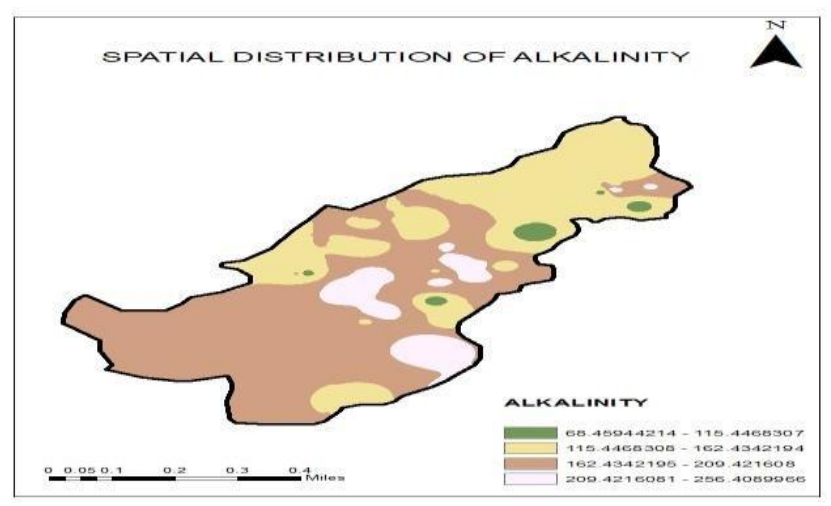

Figure 7: Spatial distribution of Alkalinity

\section{Sodium $(\mathrm{Na}+)$}

High supply of sodium content in the ground water is due to because of salts. Desirable limit of sodium content in the ground water is $200 \mathrm{mg} / \mathrm{l}$. Sodium in the ground water basin ranges between $39 \mathrm{mg} / \mathrm{l}$ to $258 \mathrm{mg} / \mathrm{l}$. Spatial distribution of Sodium concentrations are shown in Figure 8. 
Figure 8: Spatial distribution of Sodium

\section{Calcium ( $\mathrm{Ca} 2+)$}

Calcium held in water due to limestone, gypsum, dolomite and gypsiferrous minerals. Permissible limit of calcium is $75 \mathrm{mg} / \mathrm{l}$. Calcium concentration ranges from 65 $\mathrm{mg} / \mathrm{l}$ to $331 \mathrm{mg} / \mathrm{l}$. The spatial distribution of calcium concentrations are shown in Figure.9.

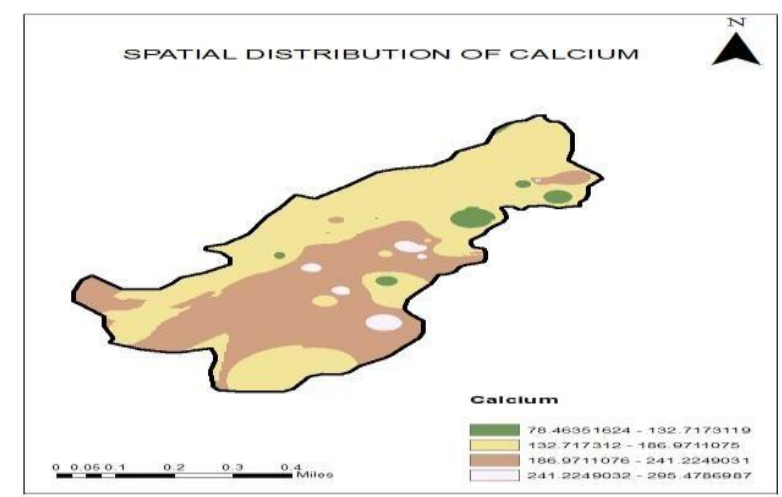

Figure 9: Spatial distribution of Calcium

Magnesium (Mg 2+)

Magnesium in water is mainly due to the presence of olivine, biotite, augite and talc minerals. Allowable limit of magnesium is $30 \mathrm{mg} / \mathrm{l}$. Quality analysis of water samples collected indicates the magnesium concentration ranges from $12 \mathrm{mg} / \mathrm{l}$ to $422 \mathrm{mg} / \mathrm{l}$. The spatial distribution of magnesium concentrations are shown in Figure.10.

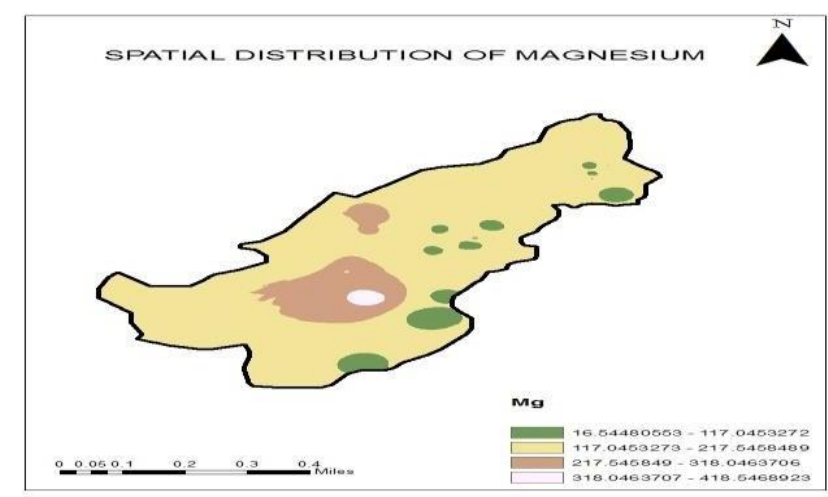

Figure 10: Spatial distribution of Magnesium

\section{Flouride}

Fluoride is found in all natural type of waters at different concentrations. The fluoride concentration in water is restricted by fluorite solubility, so that in the presence of 40 $\mathrm{mg} / \mathrm{L}$ calcium it should be limited to $3.1 \mathrm{mg} / \mathrm{L}$. surplus

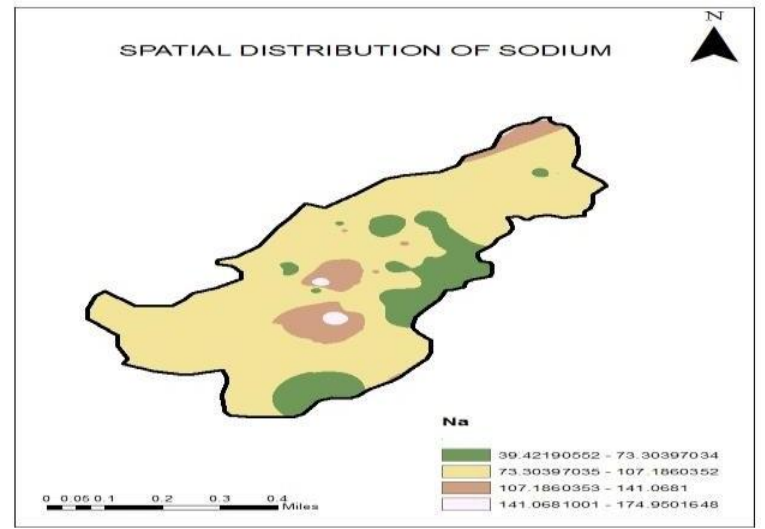

fluoride intake causes various types of fluorosis, primarily dental and skeletal fluorosis. Bureau of Indian Standards has prescribed $1 \mathrm{mg} / \mathrm{l}$ as the acceptable limit and $1.5 \mathrm{mg} / \mathrm{l}$ as the allowable limit for fluoride. The fluoride concentration of all groundwater samples in present study is in the range $0.1-0.4$ mg/l (Figure.11)

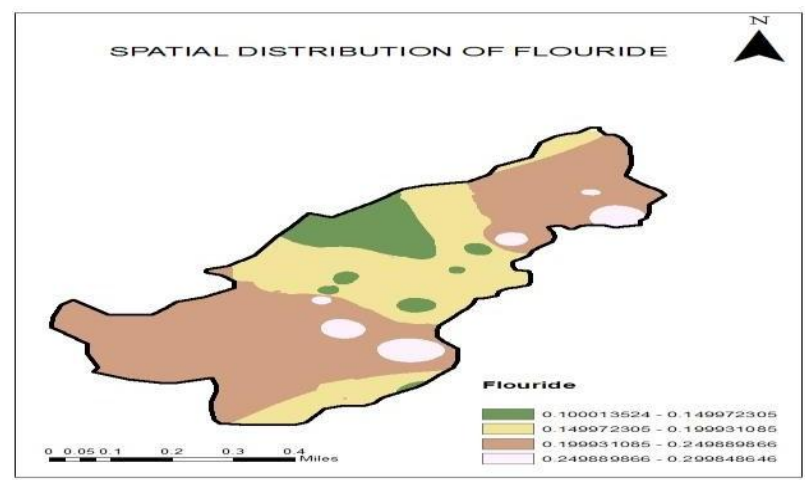

Figure 11: Spatial distribution of Flouride

Nitrates

Nitrate is the important nutrients in an ecosystem. In the present study water samples from the stations ( $\mathrm{s} 1$ to s50) showed low concentrations of nitrate ( 0 to $1.7 \mathrm{mg} / \mathrm{l})$ well below permissible levels as per the standards.

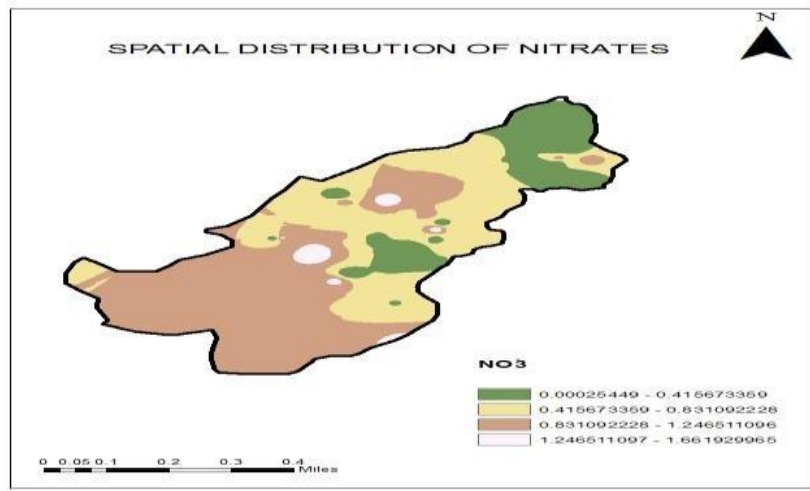

Figure 12: Spatial distribution of Nitrates

\section{CONCLUSIONS}

in the present examination, an undertaking become made to survey and to plot groundwater best of Palar Sub Basin. Spatial dissemination maps are addressed that an enormous segment of the all inclusive community of the models offered a $\mathrm{pH}$ cost inside the most extraordinary sensible limit; water high bore concerning a $\mathrm{pH}$ cost is in the restriction. The TDS cost of Palar Sub Basin is outstandingly over the top which terminations it's miles saline water. In our examination, spatial assignment guide of $\mathrm{TH}$ demonstrates that an a huge part of the groundwater tests falls inside the inconvenient class causes confirmation of cleaning chemical used for cleansing goal. Washed does not happen through all of the particles demanding hardness are actuated. The essential cation design in Palar Sub Basin is $\mathrm{Ca} 2+>\mathrm{Mg} 2+>\mathrm{Na}+$. for all intents and purposes all groundwater tests outperform the best appropriate

Blue Eyes Intelligence Engineering 
impediment of magnesium; Sodium( $\mathrm{Na}$ ) centers are inside the most sensible control. The abundance of the essential anions in Palar Sub Basin is inside the going with solicitation: $\mathrm{HCO} 3->\mathrm{Cl}->\mathrm{SO} 4$-. HCO3 thought is over the most outrageous sensible point of confinement. excess bicarbonate in water is hurting for water framework which results in soil mischief and decrease gather yield.

The Water satisfactory Index is a totally significant and a compelling gadget to survey and to report at the accompanying data to the decision makers if you should be fit for fathom the reputation of the groundwater best. the general point of view on the WQI (table of the present see quarter exhibits a by and large WQI. regardless, best eleven territories had a stunning last item with a WQI underneath one hundred. This examination allows that the use of GIS and WQI methods should give profitable information to water quality assessment for Palar Sub bowl.

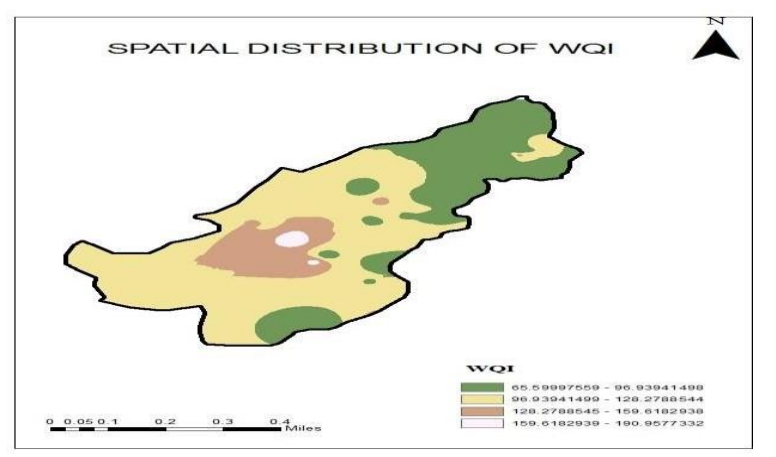

Figure 13: Spatial distribution of Water Quality Index

Table 4. Water Quality Index Values for different samples

\begin{tabular}{|c|c|c|}
\hline Sample & WQI & Status \\
\hline 1 & 98.27 & Good \\
\hline 2 & 72.993 & Good \\
\hline 3 & 76.764 & Good \\
\hline 4 & 140.395 & Poor \\
\hline 5 & 74.854 & Good \\
\hline 6 & 73.546 & Good \\
\hline 7 & 78.205 & Good \\
\hline 8 & 71.588 & Good \\
\hline 9 & 113.502 & Poor \\
\hline 10 & 73.157 & Good \\
\hline 11 & 96.17 & Good \\
\hline 12 & 122.14 & Poor \\
\hline 13 & 114.357 & Poor \\
\hline 14 & 130.422 & Poor \\
\hline 15 & 126.950 & Poor \\
\hline 16 & 132.595 & Poor \\
\hline 17 & 124.515 & Poor \\
\hline 18 & 67.386 & Good \\
\hline 19 & 69.065 & Good \\
\hline 20 & 75.072 & Good \\
\hline 21 & 55.851 & Good \\
\hline 22 & 125.739 & Poor \\
\hline 23 & 126.374 & Poor \\
\hline 24 & 117.94 & Poor \\
\hline 25 & 89.77 & Good \\
\hline 26 & 139.77 & Poor \\
\hline
\end{tabular}

\begin{tabular}{|c|c|c|}
\hline 27 & 117.59 & Poor \\
\hline 28 & 129.20 & Poor \\
\hline 29 & 65.87 & Good \\
\hline 30 & 107.03 & Poor \\
\hline 31 & 80.038 & Good \\
\hline 32 & 123.75 & Poor \\
\hline 33 & 127.37 & Poor \\
\hline 34 & 65.007 & Good \\
\hline 35 & 104.109 & Poor \\
\hline 36 & 121.605 & Poor \\
\hline 37 & 79.483 & Good \\
\hline 38 & 73.363 & Good \\
\hline 39 & 66.495 & Good \\
\hline 40 & 113.325 & Poor \\
\hline 41 & 98.362 & Good \\
\hline 42 & 145.394 & Poor \\
\hline 43 & 74.406 & Good \\
\hline 44 & 103.806 & Poor \\
\hline 45 & 98.59 & Good \\
\hline 46 & 138.35 & Poor \\
\hline 47 & 191.26 & Poor \\
\hline 48 & 168.04 & Poor \\
\hline 49 & 166.048 & Poor \\
\hline 50 & 141.808 & Poor \\
\hline
\end{tabular}

\section{REFERENCES}

1. Vasanthavigar, M., ok. Srinivasamoorthy, adequate. Vijayaragavan, R. Ganthi, S. Chidambaram, P.Anandhan, R. Manivannan and S. Vasudevan, 2010.software of water $=$ "hide"> great="tipsBox"> record For groundwater ="hide">excellent="tipsBox"> exam: Thirumanimuttar subBasin,Tamilnadu, India. Environ monitoring verify. DOI 10.1007/s10661-009-1302-1.

2. Sargaonkar, A. additionally, V. Deshpande, 2003. Headway of a famous file of defilement For floor water reliant on popular portrayal plan in Indian context,Environmental monitoring and evaluation, (89):40 three-67.

3. Ravikumar, P., R.okay. Somashekar and M. Angami, 2010. Hydrochemistry and appraisal of groundwater sensibility for water framework and appreciating motive the Markandeya River Basin, Belgaum District, Karnataka us of a, India. Environmental tracking assessment,doi:10.1007/s10661-0101399-2.

4. WHO, 1996b. Water $="$ hide">great="tipsBox"> watching: a realistic manual for the association and usage of freshwater 7339ff1fc90882f8f31ca1efdd2ac191 examinations and checking programmes.E and FN Spon, London, united kingdom.

5. WHO,2004. hints for consuming water $="$ hide">great="tipsBox"> getting geared up \%.,WHO, Geneva, Switzerland.

6. APHA (1995). elegant systems for the examination of water and waste water (APHA).

7. Kumar, M., ok. Kumari, A.L. Ramanathan and R. Sexena, 2007. A Comparative evaluation of groundwater sensibility for water framework and relishing purposes two in reality created districts of Punjab, Indian Environmental Geology [5]:553-574. 
Assessment Of Physico Chemical Parameters Of Groundwater Quality Index Of Palar Sub Basin Using Remote Sensing And Gis

8. MounaKetata-Rokbani, MoncefGuddari and Rachida Bouhlila,2011. Use of Geographical records tool and Water 7339ff1fc90882f8f31calefdd2ac191 Index and inspect ground water high-quality in EI Khairat Deep Aquifer (Enfidha,Tunisian Sahel), Iranica mag of Energyand surroundings, 2(2):133-a hundred and forty 4. 